\title{
Bacillus barbaricus sp. nov., isolated from an experimental wall painting
}

\author{
Martin Täubel, ${ }^{1,2}$ Peter Kämpfer, ${ }^{3}$ Sandra Buczolits, ${ }^{1,2}$ Werner Lubitz ${ }^{1}$ \\ and Hans-Jürgen Busse ${ }^{1,2}$ \\ ${ }^{1}$ Institut für Mikrobiologie und Genetik, Universität Wien, A-1030 Wien, Austria \\ ${ }^{2}$ Institut für Bakteriologie, Mykologie und Hygiene, Veterinärmedizinische Universität, A-1210 \\ Wien, Austria \\ ${ }^{3}$ Institut für Angewandte Mikrobiologie, Justus-Liebig-Universität, D-35392 Giessen, Germany
}

In a project concerning bacterial colonization of experimental wall paintings, a large number of isolates have been acquired with high similarities in their whole-cell protein patterns obtained after SDS-PAGE. Of this group, four strains, designated V2-BIII-A2 ${ }^{\top}, \mathrm{V} 2-\mathrm{BI}-\mathrm{A} 9, \mathrm{~V} 2-\mathrm{BI}-04$ and V2-BII$A 8$, were chosen for further characterization. Banding patterns obtained after ERIC-PCR were barely distinguishable among these four strains, indicating their affiliation within a single species. The isolates also displayed nearly identical biochemical and physiological features. The chemotaxonomic characteristics, including polar lipids, quinone systems, cell-wall diamino acid composition and fatty acid profiles, were in good agreement with those of numerous previously described Bacillus species. 16S rDNA analysis of strain V2-BIII-A2 ${ }^{\top}$ showed that this bacterium belongs to the genus Bacillus, with highest sequence similarities to Bacillus megaterium $(94 \cdot 6 \%)$, Bacillus flexus (94.4\%) and the alkaliphilic Bacillus cohnii (94.2\%). Based on almost identical biochemical, physiological and chemotaxonomic traits, ERIC-PCR-generated genomic fingerprints and comparative 16S rDNA sequence analysis, it is demonstrated that the four isolates represent a novel species of the genus Bacillus, for which the name Bacillus barbaricus sp. nov. is proposed. The type strain is V2-BIII-A2 ${ }^{\top}\left(=\mathrm{CCM} 4982^{\top}=\mathrm{DSM} 14730^{\top}\right)$.

Medieval wall paintings often suffer deterioration caused by microbial biodecay of the paintings and their groundings (Cifferi, 1999; Krumbein et al., 1990; Petushkova et al., 1989; Sorlini et al., 1987). Sampling procedures used for biodecay investigations exacerbate the destruction. In order to achieve a better understanding of bacterial colonization and its contribution to the deterioration of medieval wall paintings, a project was carried out on experimental objects. Two identical wall paintings were produced by the Academy of Fine Arts (Vienna) using materials for the background that were also employed for construction of medieval wall paintings and were painted in a combination of the secco and fresco techniques. They were exposed in two medieval Austrian chapels, the Virgilkapelle, beneath the Stephansplatz in Vienna, and the Katharinenkapelle, in Castle Herberstein in Styria. The Virgilkapelle, which is connected directly to the subway system, is characterized by a relatively stable climate, with temperatures ranging between 18 and $26^{\circ} \mathrm{C}$ and relative humidity between 64 and $86 \%$. The climate in

Published online ahead of print on 13 January 2003 as DOI 10.1099/ ijs.0.02304-0.

The GenBank/EMBL/DDBJ accession number for the 16S rDNA sequence of $B$. barbaricus V2-BIII-A2 ${ }^{\top}$ is AJ422145. the Katharinenkapelle is strongly affected by outdoor conditions. The temperature varies between -2 and $20^{\circ} \mathrm{C}$ and the relative humidity between 67 and $97 \%$. Over a period of 2 years, each painting was sampled four times on different areas that were covered with different pigments. Samples were taken by punching out material to a depth of approx. $5 \mathrm{~mm}$ using metal tubes $\left(100 \mathrm{~mm}^{2}\right)$. Isolation of bacteria was done as described by Wieser et al. (1999). For preliminary clustering of isolates displaying similar colony morphology, their protein patterns were compared after SDS-PAGE. One protein-similarity cluster was found to contain a large number of isolates (results not shown) that had been isolated from both paintings. This observation may indicate that the construction materials were already contaminated with these bacteria or that the paintings became contaminated during construction.

The 16S rDNA sequence of strain V2-BIII-A2 ${ }^{\mathrm{T}}$, selected for reference, was analysed as described previously (Buczolits et al., 2002) and a stretch of 1421 bases was obtained (positions 50-1467, Escherichia coli numbering; Brosius et al., 1978). Highest $16 \mathrm{~S}$ rDNA sequence similarities of V2-BIII-A2 ${ }^{\mathrm{T}}$ were obtained to Bacillus megaterium DSM $32^{\mathrm{T}}$ $(94 \cdot 6 \%)$, Bacillus flexus DSM $1320^{\mathrm{T}}(94 \cdot 4 \%)$ and the obligate alkaliphile Bacillus cohnii LMG $16678^{\mathrm{T}}(94 \cdot 2 \%)$. 
These values clearly allocate V2-BIII-A2 ${ }^{\mathrm{T}}$ to Bacillus rRNA group 1 (Ash et al., 1991) and demonstrate that it represents a novel species. From a collection of 35 isolates with highly similar protein patterns, including strain V2-BIII-A2 ${ }^{\mathrm{T}}$, which were isolated in October 1999 from the wall painting exposed in the chapel Virgilkapelle, strains V2-BI-09, V2-BIA4 and V2-BII-A8 were selected for further taxonomic characterization. Comparison of genomic fingerprints of these four strains obtained after ERIC (enterobacterial repetitive intergenic consensus)-PCR (Wieser \& Busse, 2000) supported their affiliation to a single species and clearly distinguished them from selected reference strains (Fig. 1).

In order to screen for isolates of this putative novel Bacillus species in subsequent samplings, isolates from both wall paintings were subjected to colony hybridization with an oligonucleotide probe (5' -GCGTTTCTTCTTATTATCCGG$\left.3^{\prime}\right)$ specific for strain V2-BIII-A2 ${ }^{\mathrm{T}}$. This probe displayed at least five mismatches with the corresponding sequences of every established Bacillus species. The distribution of this assumed species on the experimental wall paintings was studied by employing the probe in colony hybridizations with isolates from the third and fourth samplings. By this means, we were able to show that approx. 20 and $1 \%$, respectively, of the bacterial communities isolated from the wall paintings exposed in the Virgilkapelle and the Katharinenkapelle can be assumed to belong to the same species as V2-BIII-A2 ${ }^{\mathrm{T}}$ (results not shown). This assumption was supported by a high degrees of similarity in their protein patterns (results not shown).

Colonies of the four isolates V2-BIII-A2 ${ }^{\mathrm{T}}$, V2-BI-09, V2-BIA4 and V2-BII-A8 were brownish, opaque and flat and reached a maximum of $7 \mathrm{~mm}$ in diameter when grown on

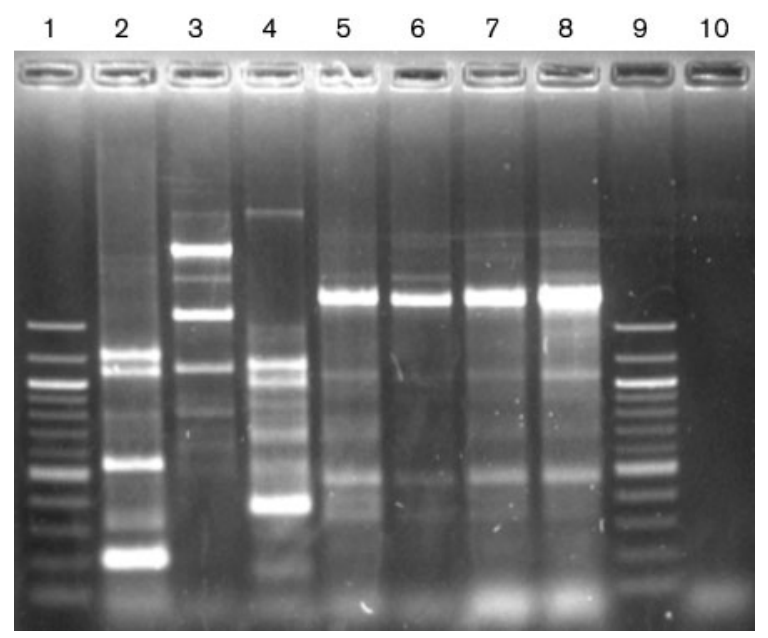

Fig. 1. ERIC-PCR-generated genomic fingerprints. Lanes: 1 and 9, 100 bp marker; 2, B. cohnii LMG $16678^{\top}$; 3, B. flexus DSM $1320^{\top} ; 4$, B. megaterium DSM $32^{\top} ; 5$, V2-BIII-A2 ${ }^{\top} ; 6$, V2-BI-04; 7, V2-BII-A8, 8, V2-BI-A9; 10, negative control.
PYES medium $(0.3 \%$ peptone from casein, $0.3 \%$ yeast extract, $0 \cdot 23 \%$ disodium succinate, $\mathrm{pH} 7 \cdot 2$ ). Younger colonies had an entire margin, but older colonies sometimes became frayed. Cells were rod-shaped, occurring singly or in filamentous chains. Spores were oval in a swollen sporangium. Cells were Gram-positive, as shown by Gramstaining, $\mathrm{KOH}$ test and aminopeptidase test (Moaledj, 1986). Growth at different temperatures was investigated on PYES medium. The four strains grew well in the range $18-37^{\circ} \mathrm{C}$; after 3 weeks of incubation, no growth was observed at 4 or $47^{\circ} \mathrm{C}$. The four strains grew only weakly on PYES medium supplemented with $2 \% \mathrm{NaCl}(\mathrm{w} / \mathrm{v})$ and no growth was observed in the presence of 5 or $10 \% \mathrm{NaCl}(\mathrm{w} / \mathrm{v})$ after 3 weeks of incubation. Good growth on PYES agar was observed for all four isolates under anaerobic conditions as described by Altenburger et al. (2002), whereas no growth was detected when the strains were incubated on PYES agar under microaerobic conditions as described by Fox et al. (1994). This lack of growth may be due to the $5 \% \mathrm{H}_{2}$ present in the microaerobic atmosphere. In experiments where the $\mathrm{pH}$ of PYES medium was adjusted with $\mathrm{HCl}$ or $\mathrm{NaOH}$ before autoclaving, the strains grew weakly at $\mathrm{pH} 6.0$ and strongly at $\mathrm{pH} 7 \cdot 2,8 \cdot 0$ and $9 \cdot 5$, indicating alkalitolerance of the isolates. The type strain (LMG $16678^{\mathrm{T}}$ ) of the alkaliphilic species B. cohnii (Spanka \& Fritze, 1993), which was incubated under the same conditions, grew strongly at $\mathrm{pH} 9 \cdot 5$, moderately at $\mathrm{pH} 8 \cdot 0$ and not at all at $\mathrm{pH} 7 \cdot 2$. When the $\mathrm{pH}$ was adjusted as described by Nielson et al. (1995) using buffered systems, no growth of the four isolates was observed at $\mathrm{pH} 7 \cdot 0,8 \cdot 0,9 \cdot 0,10 \cdot 0$ or $11 \cdot 0$, whereas B. cohnii LMG $16678^{\mathrm{T}}$ grew best at $\mathrm{pH} 8-11$. Good growth of the four strains was observed on a medium recommended for cultivation of $B$. cohnii LMG $16678^{\mathrm{T}}$ $(0.3 \%$ yeast extract, $0.5 \%$ peptone, $0.5 \% \mathrm{NaCl})$, adjusted to $\mathrm{pH} 9 \cdot 5$ with $\mathrm{Na}_{2} \mathrm{CO}_{3}$ after autoclaving.

The physiological and biochemical properties of the four novel isolates, B. megaterium DSM $32^{\mathrm{T}}$, B. flexus DSM $1320^{\mathrm{T}}$ and B. cohnii LMG $16678^{\mathrm{T}}$ were analysed as described by Kämpfer et al. (1991) and are summarized in Table 1. Strains V2-BIII-A2 ${ }^{\mathrm{T}}$, V2-BI-09, V2-BI-A4 and V2-BIIA8 only showed varying results for assimilation of 4-aminobutyrate, fumarate, L-leucine and L-ornithine. The four isolates displayed very similar acid-production profiles from carbohydrates with the API 50 CHB system (see species description).

The chemotaxonomic characteristics of the four isolates were almost identical. Peptidoglycan diamino acids were analysed in cell-wall preparations as described by Bousfield et al. (1985). Quinones were extracted and analysed as described previously (Tindall, 1990; Altenburger et al., 1996). Detection of diaminopimelic acid as the characteristic peptidoglycan diamino acid and the predominant menaquinone MK-7 were in good agreement with the characteristics of numerous Bacillus species, including B. megaterium (Claus \& Berkley, 1986) and B. flexus (this study). In contrast, Spanka \& Fritze (1993) reported that the 
Table 1. Differential physiological and biochemical properties of $B$. barbaricus sp. nov. and related species

Strains: 1, B. barbaricus sp. nov. (four strains studied); 2, B. megaterium DSM $32^{\mathrm{T}} ; 3$, B. flexus DSM $1320^{\mathrm{T}}$; 4, B. cohnii LMG $16678^{\mathrm{T}}$. +, Positive; -, negative; d, some strains positive; w, weak; ND, not determined; pNP, $p$-nitrophenyl; pNA, $p$-nitroanilide. All seven strains were positive in the catalase test (data for B. megaterium from Claus \& Berkeley, 1986), for decomposition of starch and casein (data for B. megaterium from Priest et al., 1988) and for utilization of acetate and DL-3-hydroxybutyrate. In general, positive reactions for utilization of amino acids were only weak. All seven strains were negative for utilization of L-arabinose, $\alpha$-D-melibiose, D-xylose, adonitol, D-sorbitol, putrescine, propionate, trans-aconitate, adipate, azelate, itaconate, mesaconate, suberate, $\beta$-alanine, L-tryptophan and phenylacetate and hydrolysis of pNP $\beta$-D-glucuronide, pNP phosphorylcholine, L-alanine pNA and L-proline pNA.

\begin{tabular}{|c|c|c|c|c|}
\hline Property & $1^{\star}$ & 2 & 3 & 4 \\
\hline \multicolumn{5}{|l|}{ Utilization of: } \\
\hline$N$-Acetyl-D-glucosamine & + & + & + & - \\
\hline$p$-Arbutin & - & - & + & - \\
\hline D-Cellobiose & - & - & + & - \\
\hline D-Fructose & + & + & + & - \\
\hline D-Galactose & - & - & + & - \\
\hline Gluconate & + & $-\dagger$ & $+\dagger$ & + \\
\hline D-Glucose & + & + & + & - \\
\hline D-Mannose & + & - & - & - \\
\hline D-Maltose & + & + & + & - \\
\hline L-Rhamnose & - & + & - & - \\
\hline D-Ribose & + & - & + & - \\
\hline Salicin & - & - & + & - \\
\hline Sucrose & - & - & + & - \\
\hline D-Trehalose & + & + & + & - \\
\hline i-Inositol & - & + & + & - \\
\hline Maltitol & - & - & + & - \\
\hline D-Mannitol & - & + & - & - \\
\hline cis-Aconitate & - & - & + & - \\
\hline 4-Aminobutyrate & $\mathrm{d}(1 / 4)^{a}$ & - & + & - \\
\hline Citrate & - & + & + & - \\
\hline Fumarate & $\mathrm{d}(1 / 4)^{a}$ & - & + & + \\
\hline Glutarate & - & - & + & + \\
\hline DL-Lactate & - & + & $+\dagger$ & - \\
\hline L-Malate & + & - & + & + \\
\hline Oxoglutarate & - & + & + & + \\
\hline Pyruvate & + & - & + & + \\
\hline L-Alanine & + & - & + & - \\
\hline L-Aspartate & - & + & - & - \\
\hline L-Histidine & + & + & - & - \\
\hline L-Leucine & $\mathrm{d}(2 / 4)^{b}$ & - & - & + \\
\hline L-Ornithine & $\mathrm{d}(2 / 4)^{b}$ & - & - & - \\
\hline L-Phenylalanine & + & - & - & - \\
\hline L-Proline & + & - & + & + \\
\hline L-Serine & + & - & + & + \\
\hline 3-Hydroxybenzoate & - & - & - & + \\
\hline 4-Hydroxybenzoate & - & - & - & + \\
\hline \multicolumn{5}{|l|}{ Hydrolysis of: } \\
\hline Aesculin & - & + & - & - \\
\hline pNP $\beta$-D-galactopyranoside & - & + & - & - \\
\hline pNP $\alpha$-D-glucopyranoside & - & + & - & - \\
\hline pNP $\beta$-D-glucopyranoside & - & + & - & - \\
\hline bis-pNP phosphate & - & + & - & - \\
\hline pNP phenylphosphonate & - & + & - & - \\
\hline
\end{tabular}


Table 1. cont.

\begin{tabular}{|lcccc|}
\hline Property & $\mathbf{1}^{\star}$ & $\mathbf{2}$ & $\mathbf{3}$ & $\mathbf{4}$ \\
\hline 2-Deoxythymidine-5' ${ }^{*}$-pNP phosphate & - & + & - & - \\
L-Glutamate- $\gamma$-3-carboxy pNA & - & + & - & - \\
Decomposition of: & & & & \\
Hippurate & + & ND & - & + \\
Urea & - & ND & + & $-\ddagger$ \\
Tween 20 & - & $+\S$ & + & + \\
Tween 80 & - & ND & + & + \\
Growth in the presence of: & & & & + \\
$2 \% \mathrm{NaCl}$ & W & $+\S$ & + & + \\
$5 \% \mathrm{NaCl}$ & - & $+\S$ & + & W \\
$10 \% \mathrm{NaCl}$ & - & $-\S$ & - & + \\
Nitrate reduction & - & $-\S$ & + & + \\
Growth at $47^{\circ} \mathrm{C}$ & - & $\mathrm{ND}$ & + \\
\hline
\end{tabular}

${ }^{*}$ Strain-dependent results are scored as: $a$, V2-BII-A8 negative; $b$, V2-BII-A8 and V2-BI-A9 negative.

$\dagger$ Data not in line with Priest et al. (1988).

$\ddagger$ Data from Spanka \& Fritze (1993).

§Data from Priest et al. (1988).

IIData not in line with Spanka \& Fritze (1993).

alkaliphilic species B. cohnii contains a peptidoglycan with ornithine instead of diaminopimelic acid. Analysis of total fatty acids (Kämpfer et al., 1997) showed the predominance of iso- and anteiso-branched fatty acids, typical for members of the genus Bacillus (Kämpfer, 1994). Fatty acids with chain lengths of 15 carbons $\left[\mathrm{C}_{15: 0}\right.$ anteiso (37-43\%) and $\mathrm{C}_{15: 0}$ iso (19-22\%)] were quantitatively dominant. The homogeneity in the fatty acid profiles of the four strains supports their allocation into a single species and distinguished them from the relatives B. megaterium DSM $32^{\mathrm{T}}$, B. flexus DSM $1320^{\mathrm{T}}$ and B. cohnii LMG $16678^{\mathrm{T}}$ (Table 2).

Polar lipids of V2-BIII-A2 ${ }^{\mathrm{T}}$ analysed by two-dimensional TLC according to Ventosa et al. (1993) are shown in Fig. 2. Phosphatidylethanolamine, phosphatidylglycerol and diphosphatidylglycerol were predominant in the polar lipid profile. Furthermore, we detected an unknown aminophospholipid, an unknown phospholipid, an unknown aminolipid and an unknown polar lipid. The unknown phospholipid showed chromatographic behaviour that was almost identical to that of phosphatidylcholine, but it could not be stained with Dragendorff reagent, which is commonly employed for detection of phosphatidylcholine. Glycolipids were not detected. The polar lipid profile was unaffected by the age of the biomass. Only minor quantitative differences in the amounts of certain lipids were found in two other isolates (results not shown). Similar polar lipid profiles, containing the same predominant compounds as well as the unknown phospholipid and the unknown polar lipid, were detected in B. flexus DSM $1320^{\mathrm{T}}$, B. cohnii LMG $16678^{\mathrm{T}}$ and B. megaterium DSM $32^{\mathrm{T}}$ (results not shown).

Relatively low $16 \mathrm{~S}$ rDNA sequence similarity values $(94 \cdot 2-94 \cdot 6 \%)$ to the nearest relatives indicate that
Table 2. Fatty acid compositions of $B$. barbaricus sp. nov. V2-BIII-A $2^{\top}$ and related type strains

Strains: $1, B$. barbaricus sp. nov. V2-BIII-A2 ${ }^{\mathrm{T}}$ (values in parentheses indicate the range of values detected within the three other strains of the species); 2, B. megaterium DSM $32^{\mathrm{T}} ; 3$, B. flexus DSM $1320^{\mathrm{T}} ; 4$, B. cohnii LMG $16678^{\mathrm{T}}$.

\begin{tabular}{|c|c|c|c|c|}
\hline Fatty acid & 1 & 2 & 3 & 4 \\
\hline $\mathrm{i}-\mathrm{C}_{14: 0}$ & $9 \cdot 4(8 \cdot 8-11 \cdot 0)$ & $6 \cdot 7$ & $2 \cdot 3$ & $2 \cdot 3$ \\
\hline $\mathrm{C}_{14: 0}$ & $0 \cdot 9(0 \cdot 0-1 \cdot 0)$ & - & $1 \cdot 6$ & - \\
\hline $\mathrm{i}-\mathrm{C}_{15: 1}$ AT & $0 \cdot 7(0 \cdot 8-1 \cdot 0)$ & - & - & - \\
\hline $\mathrm{i}-\mathrm{C}_{15: 0}$ & $19 \cdot 0(19 \cdot 1-21 \cdot 8)$ & $13 \cdot 9$ & $29 \cdot 6$ & $38 \cdot 4$ \\
\hline ai- $C_{15: 0}$ & $42 \cdot 8(37 \cdot 5-43 \cdot 2)$ & $70 \cdot 3$ & $36 \cdot 1$ & $17 \cdot 6$ \\
\hline $\mathrm{C}_{15: 0}$ & $0 \cdot 9(0 \cdot 8-1 \cdot 1)$ & - & - & - \\
\hline $\mathrm{C}_{16: 1} \omega 7 c$ & $4 \cdot 9(4 \cdot 6-5 \cdot 7)$ & - & $2 \cdot 0$ & $4 \cdot 0$ \\
\hline Summed feature $2^{*}$ & $1 \cdot 1(1 \cdot 2-1 \cdot 5)$ & - & - & - \\
\hline $\mathrm{C}_{16: 0} \mathrm{~N}$ & $0 \cdot 8(0 \cdot 0-1 \cdot 1)$ & - & - & - \\
\hline $\mathrm{i}-\mathrm{C}_{16: 0}$ & $6 \cdot 0(6 \cdot 0-7 \cdot 1)$ & - & - & $4 \cdot 9$ \\
\hline $\mathrm{C}_{16: 1} \omega 11 c$ & $2 \cdot 8(2 \cdot 3-2 \cdot 9)$ & - & $8 \cdot 4$ & $4 \cdot 0$ \\
\hline Summed feature $3^{*}$ & $2 \cdot 5(2 \cdot 2-3 \cdot 1)$ & - & - & - \\
\hline $\mathrm{C}_{16: 0}$ & $2 \cdot 0(1 \cdot 2-2 \cdot 4)$ & $4 \cdot 4$ & $2 \cdot 5$ & $0 \cdot 6$ \\
\hline $\mathrm{i}-\mathrm{C}_{17: 1} \omega 10 c$ & - & - & $4 \cdot 8$ & - \\
\hline Summed feature $4^{*}$ & $1 \cdot 4(1 \cdot 1-2 \cdot 0)$ & - & $5 \cdot 1$ & $7 \cdot 0$ \\
\hline ai- $C_{17: 1}$ A & $1 \cdot 3(1 \cdot 3-2 \cdot 0)$ & - & - & - \\
\hline $\mathrm{i}-\mathrm{C}_{17: 0}$ & - & - & $2 \cdot 5$ & $1 \cdot 8$ \\
\hline ai- $C_{17: 0}$ & $2 \cdot 6(1 \cdot 5-3 \cdot 0)$ & $4 \cdot 7$ & $5 \cdot 0$ & $3 \cdot 6$ \\
\hline
\end{tabular}

${ }^{*}$ Summed features represent groups of two or three fatty acids that could not be separated by GLC with the MIDI system. Summed feature 2 contained one or more of $\mathrm{C}_{12: 0}$ aldehyde or unknown ECL 10.928, i- $\mathrm{C}_{16: 1} \mathrm{I}$ and $\mathrm{C}_{14: 0}$ 3-OH. Summed feature 3 contained $\mathrm{C}_{16: 1} \omega 7 c$ and/or $\mathrm{C}_{15: 0}$ iso $2 \mathrm{OH}$. Summed feature 4 contained $\mathrm{i}-\mathrm{C}_{17: 1}$ $\mathrm{I}$ and/or ai- $\mathrm{C}_{17: 1} \mathrm{~B}$. 


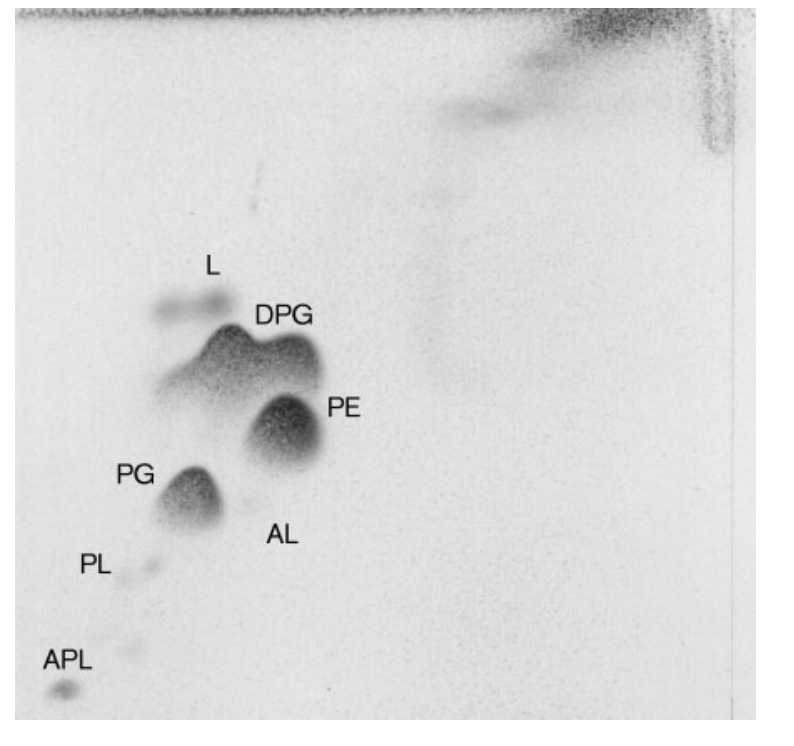

Fig. 2. Two-dimensional TLC of the polar lipids of Bacillus barbaricus V2-BIII-A2 ${ }^{\top}$. Abbreviations: DPG, diphosphatidylglycerol; PG, phosphatidylglycerol; PE, phosphatidylethanolamine; $\mathrm{PL}$, unknown phospholipid; APL, unknown aminophospholipid; $\mathrm{AL}$, unknown aminolipid; L, unknown polar lipid.

V2-BIII-A2 ${ }^{\mathrm{T}}$ represents a novel species of the genus Bacillus. Almost identical genomic fingerprints (Fig. 1), highly similar whole-cell protein patterns (results not shown) and fatty acid profiles (Table 2) and nearly identical biochemical and physiological properties (Table 1) provide further evidence that the four strains V2-BIII-A2 ${ }^{\mathrm{T}}, \mathrm{V} 2-\mathrm{BI}-$ 04, V2-BII-A8 and V2-BI-A9 represent a single species of the genus Bacillus. It can be distinguished from its close relatives within the genus, $B$. megaterium DSM $32^{\mathrm{T}}$, B. flexus DSM $1320^{\mathrm{T}}$ and B. cohnii LMG $16678^{\mathrm{T}}$, on the basis of genomic fingerprints, biochemical/physiological traits and differences in fatty acid profiles and polar lipid patterns. In conclusion, we describe a novel species, for which we propose the name Bacillus barbaricus sp. nov.

\section{Description of Bacillus barbaricus sp. nov.}

Bacillus barbaricus (bar.ba'ri.cus. L. adj. barbaricus strange, foreign, referring to the strange behaviour towards growth at different $\mathrm{pH}$ ).

Cells are Gram-positive, non-motile rods that produce subterminal, oval endospores in a swollen sporangium. Cells are $0.5 \mu \mathrm{m}$ wide and $4-5 \mu \mathrm{m}$ long. Colonies are brownish, opaque, circular, flat and 3-7 $\mathrm{mm}$ in diameter when grown on PYES agar. Facultatively anaerobic. Catalase-positive. Oxidase- and urease-negative. Nitrate is not reduced. Indole and $\mathrm{H}_{2} \mathrm{~S}$ are not produced. Alkalitolerant. Good growth occurs at temperatures ranging from 18 to $37^{\circ} \mathrm{C}$. No growth at 4 or $47^{\circ} \mathrm{C}$ or in the presence of 5 or $10 \% \mathrm{NaCl}$, and only weak growth in $2 \% \mathrm{NaCl}$. Acid is produced from D-glucose, $\mathrm{N}$-acetylglucosamine, aesculin, maltose, trehalose, starch and glycogen. Acid production is variable from $\mathrm{D}$-fructose (V2-BIII-A2 ${ }^{\mathrm{T}}$ is weakly positive), galactose, methyl $\alpha$-Dglucoside, lactose, sucrose and D-turanose (V2-BIII-A2 ${ }^{\mathrm{T}}$ is negative). No acid is produced from glycerol, erythritol, D-arabinose, ribose, D-xylose, L-xylose, adonitol, methyl $\beta$-xyloside, D-mannose, L-sorbose, rhamnose, dulcitol, inositol, mannitol, sorbitol, methyl $\alpha$-D-mannoside, amygdalin, arbutin, salicin, cellobiose, melibiose, inulin, melezitose, D-raffinose, xylitol, $\beta$-gentiobiose, D-lyxose, D-tagatose, D-fucose, L-fucose, D-arabitol, L-arabitol, gluconate, 2-ketogluconate or 5-ketogluconate. Other physiological and biochemical characteristics are given in Table 1. The cell-wall diamino acid is diaminopimelic acid and MK-7 is the predominant menaquinone. The polar lipid profile is composed of the major compounds phosphatidylethanolamine, phosphatidylglycerol and diphosphatidylglycerol and minor amounts of an unknown phospholipid, an unknown aminophospholipid, an unknown aminolipid and one unknown polar lipid. The fatty acid profile consists of the predominant compounds ai- $\mathrm{C}_{15: 0}$ and $\mathrm{i}-\mathrm{C}_{15: 0} ; \mathrm{i}-\mathrm{C}_{14: 0}$ and $\mathrm{i}-\mathrm{C}_{16: 0}$ are present in moderate amounts.

The type strain, V2-BIII-A2 ${ }^{\mathrm{T}} \quad\left(=\mathrm{CCM} \quad 4982^{\mathrm{T}}=\mathrm{DSM}\right.$ $\left.14730^{\mathrm{T}}\right)$, was isolated from an experimental wall painting exposed in the Virgilkapelle in Vienna, Austria.

\section{Acknowledgements}

This work was supported by a grant from the Austrian Fonds zur Förderung der Wissenschaftlichen Forschung (P12820 MOB). We are grateful to Hans Trüper for advice on nomenclatural problems.

\section{References}

Altenburger, P., Kämpfer, P., Makristathis, A., Lubitz, W. \& Busse, H.-J. (1996). Classification of bacteria isolated from a medieval wall painting. J Biotechnol 47, 39-52.

Altenburger, P., Kämpfer, P., Schumann, P., Vybiral, D., Lubitz, W. \& Busse, H.-J. (2002). Georgenia muralis gen. nov., sp. nov., a novel actinobacterium isolated from a medieval wall painting. Int $J$ Syst Evol Microbiol 52, 875-881.

Ash, C., Farrow, J. A. E., Wallbanks, S. \& Collins, M. D. (1991). Phylogenetic heterogeneity of the genus Bacillus revealed by comparative analysis of small-subunit-ribosomal RNA. Lett Appl Microbiol 13, 202-206.

Bousfield, I. J., Keddie, R. M., Dando, T. R. \& Shaw, S. (1985). Simple rapid methods of cell wall analysis as an aid in the identification of aerobic coryneform bacteria. In Chemical Methods in Bacterial Systematics, pp. 221-236. Edited by M. Goodfellow \& D. E. Minnikin. London: Academic Press.

Brosius, J., Palmer, M. L., Kennedy, P. J. \& Noller, H. F. (1978). Complete nucleotide sequence of a $16 \mathrm{~S}$ ribosomal RNA gene from Escherichia coli. Proc Natl Acad Sci U S A 75, 4801-4805.

Buczolits, S., Denner, E. B. M., Vybiral, D., Wieser, M., Kämpfer, P. \& Busse, H.-J. (2002). Classification of three airborne bacteria and proposal of Hymenobacter aerophilus sp. nov. Int J Syst Evol Microbiol 52, 445-456. 
Cifferi, O. (1999). Microbial degradation of paintings. Appl Environ Microbiol 65, 879-885.

Claus, D. \& Berkeley, R. C. W. (1986). Genus Bacillus Cohn 1872, $174^{\mathrm{AL}}$. In Bergey's Manual of Systematic Bacteriology, vol. 2, pp. 1105-1139. Edited by P. H. A. Sneath, N. S. Mair, M. E. Sharpe \& J. G. Holt. Baltimore: Williams \& Wilkins.

Fox, J. G., Dewhirst, F. E., Tully, J. G., Paster, B. J., Yan, L., Taylor, N. S., Collins, M. J., Jr, Gorelick, P. L. \& Ward, J. M. (1994). Helicobacter hepaticus sp. nov., a microaerophilic bacterium isolated from livers and intestinal mucosal scrapings from mice. J Clin Microbiol 32, 1238-1245.

Kämpfer, P. (1994). Limits and possibilities of total fatty acid analysis for classification and identification of Bacillus species. Syst Appl Microbiol 17, 86-98.

Kämpfer, P., Steiof, M. \& Dott, W. (1991). Microbiological characterization of a fuel-oil contaminated site including numerical identification of heterotrophic water and soil bacteria. Microb Ecol 21, 227-251.

Kämpfer, P., Denner, E. B. M., Meyer, S., Moore, E. R. B. \& Busse, H.-J. (1997). Classification of "Pseudomonas azotocolligans" Anderson 1955, 132, in the genus Sphingomonas as Sphingomonas trueperi sp. nov. Int J Syst Bacteriol 47, 577-583.

Krumbein, W. E. \& Petersen, K. (1990). Mikroorganismen beschleunigen den Zerfall von mittelalterlichen Wandgemälden. Wandmalereischäden Arbeitshefte Denkmalplege Niedersachsen 8, 115-121.

Moaledj, K. (1986). Comparison of Gram-staining and alternate methods, $\mathrm{KOH}$ test and aminopeptidase activity in aquatic bacteria: their application to numerical taxonomy. J Microbiol Methods 5, 303-310.
Nielsen, P., Fritze, D. \& Priest, F. G. (1995). Phenetic diversity of alkaliphilic Bacillus strains: proposal for nine new species. Microbiology 141, 1745-1761.

Petushkova, Y. P., Lyalikova, N. N. \& Poglasova, M. N. (1989). Microorganisms discovered on the frescoes of the Ferapoint Monastery. Mikrobiologiya 58, 1021-1030.

Priest, F. G., Goodfellow, M. \& Todd, C. (1988). A numerical classification of the genus Bacillus. J Gen Microbiol 134, 1847-1882.

Sorlini, C., Sacchi, M. \& Ferrari, A. (1987). Microbiological deterioration of Gambara's frescos exposed to open air in Brescia, Italy. Int Biodeterior 23, 167-179.

Spanka, R. \& Fritze, D. (1993). Bacillus cohnii sp. nov., a new, obligately alkaliphilic, oval-spore-forming Bacillus species with ornithine and aspartic acid instead of diaminopimelic acid in the cell wall. Int J Syst Bacteriol 43, 150-156.

Tindall, B. J. (1990). A comparative study of the lipid composition of Halobacterium saccharovorum from various sources. Syst Appl Microbiol 13, 128-130.

Ventosa, A., Marquez, M. C., Kocur, M. \& Tindall, B. J. (1993). Comparative study of "Micrococcus sp." strains CCM 168 and CCM 1405 and members of the genus Salinicoccus. Int J Syst Bacteriol 43, 245-248.

Wieser, M. \& Busse, H.-J. (2000). Rapid identification of Staphylococcus epidermidis. Int J Syst Evol Microbiol 50, 1087-1093.

Wieser, M., Schumann, P., Martin, K., Altenburger, P., Burghardt, J., Lubitz, W. \& Busse, H.-J. (1999). Agrococcus citreus sp. nov., isolated from a medieval wall painting of the chapel of Castle Herberstein (Austria). Int J Syst Bacteriol 49, 1165-1170. 